\title{
BREVES CONSIDERAÇÕES SOBRE A (IM)POSSIBILIDADE DE APLICAÇÃO DA TEORIA DA DUPLA IMPUTAÇÃO EM MATERIA PENAL AMBIENTAL
}

Rogerio Borba da SILVA ${ }^{1}$

Giovanna Curvelo Bernardes da SILVA²

ISSUE DOI: $10.21207 / 1983.4225 .1007$

\section{RESUMO}

O presente artigo visa analisar a viabilidade de aplicação da responsabilização penal às pessoas jurídicas causadoras de crimes ambientais, bem como breves considerações sobre a necessidade de

\footnotetext{
${ }^{1}$ Doutor em Sociologia pelo Instituto Universitário de Pesquisas do Estado do Rio de Janeiro. Possui graduação em Direito pela Universidade Candido Mendes, Mestrado em Direito pelo Centro Universitário Fluminense. Professor do Programa de Pós-Graduação em Direito da Universidade Veiga de Almeida-RJ desde abril de 2019. É Coordenador do projeto de pesquisa "Licenciamento Ambiental Municipal: Implementação e Aperfeiçoamento pós LC 140\2011. Foi Conselheiro Seccional e Presidente da Comissão de Ensino Jurídico da Ordem dos Advogados do Brasil - Seção do Rio de Janeiro (2010-2012). É Diretor do Fundo de Previdência Multipatrocinado da Ordem dos Advogados do Brasil - Seção do Rio de Janeiro. Foi Assessor Jurídico Chefe da Fundação Superintendência Estadual de Rio e Lagoas do Estado do Rio de Janeiro (2007-2008), auxiliando na implementação do Instituto Estadual do Ambiente no Rio de Janeiro. Tem experiência de pesquisa em Direito Ambiental, Direito Educacional e Sociologia ambiental. É autor de livros e diversos artigos na área jurídica. Membro da Liga Mundial de Advogados Ambientalistas, da Fundação Internacional de Sustentabilidade Ambiental e Territorial e do Instituto dos Advogados Brasileiros. Advogado e Parecerista.

${ }^{2}$ Graduada em Direito pelo Centro Universitário IBMEC. Advogada.
} 
aplicação da teoria da dupla imputação para que se faça possível a aplicação do instituto supramencionado, constatando-se que a jurisprudência tem caminhado no sentido de reconhecer a possibilidade de criminalização das pessoas jurídicas sem a necessidade de aplicação da teoria da dupla imputação. A presente pesquisa se valeu do método de revisão bibliográfica.

Palavras-chave: Crimes Ambientais; Responsabilidade. Penal Ambiental; Pessoa Jurídica; Teoria da Dupla Imputação.

\begin{abstract}
This paper aims to analyze the feasibility of applying criminal liability to legal entities that cause environmental crimes, as well as brief considerations on the need to apply the double imputation theory in order to make possible the application of the aforementioned institute, evidencing that jurisprudence has moved towards recognizing the possibility of criminalizing legal entities without the need to apply the double imputation theory. This research used the bibliographic review method.
\end{abstract}

Keywords: Environmental Crimes; Responsibility. Environmental Penal; Legal person; Double Imputation Theory.

\title{
1 INTRODUÇÃO
}

O meio ambiente ecologicamente equilibrado deve ser resguardado com afinco pelo ordenamento jurídico brasileiro, por se tratar de um direito fundamental de ampla importância para toda a coletividade, e que está intimamente relacionado à dignidade existencial humana, tal qual a reconhecida pelo Supremo Tribunal Federal no âmbito da ADI 35401 (Supremo Tribunal Federal, 2015).

Neste sentido, a pesquisa busca discutir sobre a possibilidade, à luz do direito penal ambiental, da punição de pessoas juridicas em razão de cometimento de crimes ambientais.

$\mathrm{O}$ artigo se insere no ramo das Ciências Jurídicas e Sociais, nas áreas do Direito Ambiental, sendo analisada em uma perspectiva doutrinaria e jurisprudencial.

Apresenta-se, então, o seguinte questionamento: o Estado pode punir pessoa jurídica pelo cometimento de crimes ambientais? A hipótese trabalhada reconhece a sua possibilidade, consideradas as posições doutrinárias e o posicionamento jurisprudencial consolidado. A metodologia adotada foi a bibliográfica e documental.

A relevância acadêmica da pesquisa se demonstra no sentido de contribuir para o reconhecimento e consolidação do papel do Estado em punir pessoas juridicas em decorrência do cometimento de crimes ambientais. 
O presente artigo abordará a Responsabilidade Penal da Pessoa Jurídica, as correntes doutrinarias acerca da possibilidade de aplicação de sanção penal às Pessoas Jurídicas e o Leading Case proveniente do REsp $\mathrm{n}^{\circ}$ 564.960/SC, as penas aplicáveis às Pessoas Jurídicas. Por fim, discutirse-a, de forma breve e superficial, a Teoria da Dupla Imputação.

A responsabilidade penal da pessoa jurídica é um tema que desperta controvérsias entre os operadores e estudiosos do direito penal e, é em torno desta problemática que se fundamenta o presente estudo. Objetiva-se descobrir se o sistema penal vigente é capaz de reconhecer e justificar adequadamente a responsabilidade penal da pessoa jurídica, em especial relativamente à teoria da dupla imputação, prestigiada por muito tempo no Superior Tribunal de Justiça.

\section{RESPONSABILIDADE PENAL DA PESSOA JURÍDICA}

Este trabalho aborda a possibilidade de responsabilização penal de pessoas jurídicas causadoras de ilícito ambiental por ser essa uma temática de grande relevância, tanto do ponto de vista das políticas públicas voltadas a repressão de ilícitos praticadas por essas pessoas jurídicas, tanto do ponto de vista jurídico-dogmático.

A priori, a concepção tradicional do sujeito ativo de crime acredita, em apertada síntese, que autor de crime é toda pessoa física capaz, ou seja, maior de dezoito anos com potencial suficiente para discernir o caráter ilícito do fato que pratica. O Direito Penal fundamenta a incidência de sanção penal na culpabilidade do agente infrator, e a culpabilidade pressupõe a capacidade de compreender o caráter ilícito do fato (imputabilidade penal).

Essa definição clássica supracitada é corroborada pela Constituição da República, eis que a carta constitucional consagra em seu texto o princípio da pessoalidade da pena, quando veda que a pena ultrapasse a pessoa física do condenado, no art. 5, XLV (BRASIL, 1988), e em razão disso, existe uma certa resistência doutrinária no sentido de se considerar a responsabilização penal da pessoa jurídica possível, uma vez que essa pessoa não é dotada de vontade e consciência para a prática do ato delitivo. E é nesse sentido que Bitencourt defende que:

a conduta (ação ou omissão), pedra angular da Teoria do Crime, é produto exclusivo do homem. A capacidade de ação, de culpabilidade, 
exige a presença de uma vontade, entendida como faculdade psíquica da pessoa individual, que somente o ser humano pode ter (BITENCOURT, 1999, p. 199).

Contudo, a despeito dessa primeira corrente, o art. $225, \S 3^{\circ}$, da mesma Constituição da República (BRASIL, 1988), contrapõe a teoria clássica pois assevera de forma clara que as pessoas físicas ou jurídicas, causadoras de atividades lesivas ao meio ambiente se sujeitam a sanções penais e administrativas, independentemente do dever de reparar o dano causado (responsabilidade civil).

Em harmonia com o mandamento constitucional supramencionado, o art. $3^{\circ}$, caput e parágrafo único da Lei de Crimes Ambientais (Lei 9605/98), (BRASIL, 1998), dispõe expressamente que as pessoas jurídicas serão responsabilizadas penalmente nos casos em que a infração seja cometida por decisão de seu representante legal ou contratual, ou de seu órgão colegiado, no interesse ou benefício da sua entidade, não excluindo a responsabilidade das pessoas físicas autoras, co-autoras ou partícipes do mesmo fato.

Pode-se dizer, então, que além da preocupação político-social, o próprio texto constitucional de 1988 abriu espaço para a análise acerca da possibilidade ou da impossibilidade de responsabilização criminal das pessoas jurídicas no âmbito do direito ambiental. Não restam dúvidas quanto ao fato de que as pessoas físicas envolvidas em crimes ambientais, serão responsabilizados pelos danos, diretos ou indiretos, por eles causados ao meio ambiente, contudo, é de fácil percepção que nem sempre essa imputação é suficiente para coibir eficazmente a danosidade ambiental.

Isto porque, é certo que, normalmente, as pessoas jurídicas representam, pela natureza das suas atividades, uma ameaça muito maior de gerar danos catastróficos ao ambiente em detrimento daquelas que agem individualmente. Porém, não obstante a esse cenário, subsiste no nosso ordenamento jurídico resistência quanto o reconhecimento da imputação de responsabilidade criminal às pessoas jurídicas que violam a dimensão da essencialidade do meio ambiente equilibrado, usualmente em prol do proveito econômico da sua atividade empresarial.

Dessa forma, fica o ordenamento jurídico brasileiro defasado na prevenção de ilícitos ambientais, eis que esvaziado o preceito do princípio da prevenção oriundo do direito ambiental. Isto porque, as corporações e instituições quando da análise das suas práticas de gestão, optarão por aquela mais benéfica e menos custosa, o que implica em severos danos ao 
meio ambiente equilibrado, uma vez que insuficientes os mecanismos punitivos ou preventivos.

A criminalidade econômica, a corrupção, a lavagem de dinheiro e especialmente crimes ao meio ambiente não teriam seus bens jurídicos resguardados por ausência de norma jurídica capaz de punir aqueles que de fato os praticaram. À vista desta conjuntura é que surgem concepções visando o reconhecimento da possibilidade de aplicação de responsabilidade penal às pessoas jurídicas.

Como já mencionado, a responsabilização da pessoa física causadora de dano ambiental é patente no ordenamento jurídico brasileiro, e para a imputação de responsabilização a essas pessoas naturais são necessários os componentes da ação, decisão e conhecimento pelo mesmo indivíduo, o que não é de difícil verificação se a conduta danosa for praticada de forma individualizada. Contudo, esses requisitos tornam, em princípio, impossível a responsabilização das pessoas físicas integrantes de uma pessoa jurídica em atuação perante essas corporações, eis que muitas vezes não se pode atribuir essas três elementares individualmente, tendo em vista que cada indivíduo concorre de forma distinta para o resultado danoso e/ou criminoso.

Dito isso, verifica-se que essas condições delineiam as dificuldades de determinação normativa de competências e de responsabilidades dentro da estrutura da empresa, o que vem representando um verdadeiro obstáculo à imputação jurídico-penal no âmbito da criminalidade praticada por intermédio da pessoa jurídica, tanto em razão do cenário que identificamos acima, de desconfiguração da conduta típica, como em razão das dificuldades de prova do ato ilícito e suas circunstâncias (COSTA, 1992).

Diante desse diapasão, de dificuldade de se delimitar o grau de envolvimento de cada indivíduo, é que as propostas de responsabilização coletiva vêm prosperando no ordenamento jurídico, de modo que a possibilidade de criminalização da pessoa jurídica, para que aqueles que praticaram o ilícito ao meio ambiente não fiquem impunes, ganhou força.

Vladimir Passos Freitas, quando diz que "A complexibilidade dos interesses em jogo na estrutura das empresas pode levar à irresponsabilidade organizada dos indivíduos"(FREITAS, 2002, p.45/49), traduz o entendimento de que insistir em uma estrutura individual de imputação para tratar da responsabilidade de infrações praticadas no âmago de pessoas jurídicas, nos levaria a um cenário de irresponsabilidade 
organizada e consequente dificuldade de responsabilização dos agentes praticantes de condutas lesivas ao meio ambiente.

Assim, punir somente os dirigentes das pessoas jurídicas que causam danos ao meio ambiente é ineficaz, pois ele é substituível e poderá até mesmo, a depender da pena imposta, exercer as suas funções dentro do ente visando o lucro. Por essa razão é imprescindível que a própria pessoa jurídica seja responsabilizada.

Nota-se então, que a verificação de condutas individualizadas no âmbito das grandes corporações é complexa e dificultosa, e que, portanto, se faz extremamente necessária a adoção de medidas capazes de sanar os obstáculos que dificultam a responsabilização penal das pessoas executoras de ilícitos.

Ademais, outro aspecto relevante a ser mencionado em favor do reconhecimento da responsabilização penal das pessoas jurídicas, é o de que essa responsabilização serviria como uma forma de prevenção à práticas delituosas, como já explorado de forma sucinta anteriormente, visto que essas empresas estariam mais suscetíveis de serem mais severamente punidas e prejudicadas economicamente, o que leva a crer que se sentiriam, de certo modo, inibidas ou dissuadidas a praticar tais condutas.

Contudo, em contraposição às posições favoráveis, também existem argumentos contrários a esse instituto, a exemplo: (i) violação ao princípio da isonomia, uma vez que a partir do reconhecimento da pessoa jurídica como autora, as pessoas físicas causadoras do ilícito acabariam recebendo um tratamento menos rigoroso, sendo beneficiadas; (ii) violação ao princípio da humanização da pena; (iii) falta de legitimidade para o direito de regresso; (iv) ofensa a princípios relativos à Teoria do Crime; (v) violação a regra do lugar do delito, eis que uma pessoa jurídica pode se desmembrar em várias e possuir diferentes sedes em diferentes localidades; (vi) inobservância do tempo do crime, dentre outros.

Posto o cenário conflitante acerca da possibilidade ou impossibilidade do reconhecimento da responsabilidade penal às pessoas jurídicas, a doutrina se posicionou a fim de resolver tal questão, o que será objeto de análise deste projeto a seguir.

\subsection{DAS CORRENTES DOUTRINÁRIAS ACERCA DA POSSIBILIDADE DE APLICAÇÃO DE SANÇÃO PENAL ÀS}




\section{PESSOAS JURÍDICAS E O LEADING CASE PROVENIENTE DO RESP №. 564.960/SC}

$\mathrm{O}$ ordenamento jurídico brasileiro tratou do tema da responsabilização penal das pessoas jurídicas, inicialmente, no art. 225 da Constituição da República (BRASIL, 1988) e posteriormente regulamentou a temática pela Lei 9.605/98 (BRASIL, 1998), que possibilitou inovações a tutela penal do meio ambiente.

O advento da Lei $n^{\circ}$ 9.605/98 (BRASIL,1998) deu ensejo ao reconhecimento da possibilidade de imputação penal às pessoas jurídicas, desde que fossem atendidos os pressupostos estabelecidos no seu art. $3^{\circ}$, quais sejam, o de que a infração penal fosse cometida por decisão de seu representante legal ou contratual ou de seu órgão colegiado; e que a infração penal fosse cometida no interesse ou benefício da sua entidade.

Embora tenha passado a haver previsão legal expressa no sentido da responsabilização penal ambiental da pessoa jurídica infratora, muitos penalistas advertem que essa previsão possuiria fragilidades teóricas importantes. Em resumo, as correntes negativistas, advogam a tese de que faltaria à pessoa jurídica o elemento central da culpabilidade, pois, como entes fictícios, as pessoas jurídicas seriam incapazes de compreender o caráter ilícito do fato que praticam. Assim é que, estabelecer a responsabilidade penal das pessoas jurídicas significaria trabalhar com um Direito Penal objetivo, rompendo, por tabela, com o princípio da pessoalidade da pena (pois quem unicamente praticaria o crime seriam as pessoas naturais, nunca a pessoa jurídica).

No entanto, há correntes que caminham em sentido contrário, afirmando, por conseguinte, a responsabilidade penal da pessoa jurídica. Uma dessas correntes é a que defende a possibilidade de responsabilização penal da Pessoa Jurídica causadora de dano ambiental e possui fulcro na Teoria dos Órgãos, de Otto Gierke.

A Teoria do Órgão, em apertada síntese, consiste no entendimento de que a entidade é constituída por órgãos e, esses funcionam como parte dela, de modo que todas as suas manifestações de vontades seriam reputadas como da própria entidade. É analisada sobre a óptica da unicidade entre a função e o agente, formando uma só instituição. Para Gierke a pessoa jurídica seria uma realidade técnica, com vontade própria e autônoma, que é diversa da vontade de seus membros (GIERKE, 1887). 
Dito isso, dessas correntes nasceram quatro novas correntes. A primeira delas, adotada por autores como Cézar Roberto Bittencourt, Miguel Reale Jr e José Cretela Jr, acreditava não ser possível a responsabilização penal da pessoa jurídica. Isto porque, a Constituição Federal (BRASIL, 1988) não previu em seu texto constitucional a responsabilidade penal das pessoas

jurídicas, se limitando a positivar a responsabilidade administrativa dessas entidades, e essa interpretação se dá a partir do art. $225, \S 3^{\circ}$ do refiro diploma. Logo, neste caso, fala-se que as pessoas físicas estão sujeitas a sanções penais, e as pessoas físicas se sujeitariam apenas as sanções administrativas.

Tal como se mencionou, uma segunda corrente, também sustenta a impossibilidade da responsabilização penal às pessoas jurídicas, contudo, se fundamenta na crítica de que a noção de responsabilidade penal da pessoa jurídica é incompatível com a teoria do crime adotada pelo ordenamento jurídico brasileiro. E é esta corrente que se baseia na Teoria da Ficção Jurídica de Savigny, que julga que as pessoas jurídicas não podem sofrer essa espécie de responsabilização pois despidas de capacidade para prática de condutas e de culpabilidade, não podendo praticar condutas tipicamente humanas (GOMES; CUNHA, 2009, p. 691). Esse é o entendimento de, René Ariel Dotti, Alberto Silva Franco, Zafaroni e outros.

Sob uma outra percepção se originaram a terceira e a quarta correntes que defendem a possibilidade de responsabilização penal da pessoa jurídica, e asseveram que a pessoa jurídica é ente autônomo e distinto dos membros que a compõem, dotado de vontade própria, e que por tal motivo, possuem capacidade para cometimento de crimes ambientais e consequentemente para serem responsabilizadas criminalmente pelo ilícito por elas praticado.

Contudo, a terceira corrente que se fundamenta na interpretação restritiva do art. 225, $\S 3^{\circ}$ da Constituição da República (BRASIL, 1988), acreditava ser plenamente possível a responsabilização da pessoa jurídica no caso de cometimento de crimes ambientais, em virtude da própria determinação do texto constitucional. Importante dizer que, por fazer uma análise restritiva do referido dispositivo, essa corrente defendia não ser necessária a aplicação da dupla imputação das pessoas jurídicas e pessoas físicas simultaneamente. Essa corrente é defendida por Vladimir e Gilberto Passos de Freitas. 
A quarta corrente defendia a aplicação da responsabilidade penal das pessoas jurídicas desde que houvesse em conjunto a responsabilização da pessoa física coautora, o que implicaria no fato de que o Ministério Público não poderia intentar ação apenas contra a pessoa jurídica, sob pena de caracterização de inépcia e extinção do feito, esse entendimento se dá com base na redação do art. $3^{\circ}$ da Lei 9.605/98 (BRASIL, 1998). Essa é a posição adotada por Édis Milaré.

Assim sendo, em virtude da instauração de debates acerca do tema na doutrina, em 2005 o Superior Tribunal de Justiça se posicionou no julgamento do Recurso Especial 564.960/SC

(Superior Tribunal de Justiça, 2005), que veio a se tornar o leading case do assunto, decidindo pela possibilidade de responsabilização das pessoas jurídicas. Contudo, esse instituto só é passível de aplicação para aos casos que envolvam crimes ambientais, sem prejuízo de tentativas para que incida sobre outras práticas delitivas no âmbito das empresas, mas ainda sem êxito nesse segundo cenário.

Assim, verifica-se então que essa responsabilização penal das pessoas jurídicas já é possível no âmbito do direito ambiental, ficando, inclusive, reconhecido no RESP 564.960/SC (Superior Tribunal de Justiça, 2005) que a pessoa jurídica é capaz de praticar uma ação típica quando agir em nome próprio no meio social e existir de forma independente às pessoas físicas, estando, portanto, dotada de prerrogativas suficientes para ser responsabilizada penalmente.

\subsection{DAS PENAS APLICÁVEIS ÀS PESSOAS JURÍDICAS}

Diante do reconhecimento da possibilidade de imputação da responsabilidade penal às pessoas jurídicas, a Lei de Crimes Ambientais disciplinou algumas formas de punir penalmente uma pessoa jurídica. $\mathrm{O}$ art. 21 da Lei 9.605/98 (Lei de Crimes Ambientais) (BRASIL, 1998) elenca quais são as penas passíveis de serem aplicadas às pessoas jurídicas causadoras de ilícitos ambientais, quais sejam, multa, penas restritivas de direitos, e prestação de serviços à comunidade. Interessante mencionar que a aplicação dessas sanções poderá se dar de forma isolada, cumulativa ou alternada.

As penas restritivas de direitos podem consistir em (i) suspensão total ou parcial de atividade, quando tais atividades estiverem infringindo 
disposições legais ou regulamentares relativas à proteção do meio ambiente; (ii) interdição temporária de estabelecimento, quando ficar constatado que o estabelecimento, obra ou a atividade estiver funcionando sem a devida autorização, ou com violação de dispositivo legal ou regulamentar; (iii) proibição de contratar com o Poder Público, não excedendo ao prazo de 10 anos, todas com base no art. $22, \S 1^{\circ}, \S 2^{\circ}$ e $\S 3^{\circ}$ da Lei 9.605/98 (BRASIL, 1998).

Ao passo que os serviços prestados à comunidade se traduzem no (i) custeio de programas e de projetos ambientais; (ii) execução de obras de recuperação de áreas degradadas, (iii) manutenção de espaços públicos; (iv) contribuições a entidades ambientais ou culturas de natureza pública, e estão disciplinados no art. 23 da Lei de Crimes Ambientais (BRASIL, 1998).

Além dessas sanções, é prevista no art. 24 da referida legislação infraconstitucional, (BRASIL, 1998), a pena excepcional de liquidação forçada, que nada mais é do que a dissolução da pessoa jurídica, sendo essa a sanção mais severa aplicada às pessoas jurídicas.

No entanto, ainda se discutia sobre a desnecessidade ou necessidade de aplicação da teoria da dupla imputação para que ocorresse a responsabilização penal dessas pessoas jurídicas, o que será objeto de análise do tópico seguinte.

\section{DA TEORIA DA DUPLA IMPUTAÇÃO}

Embora superada a questão da responsabilização penal da pessoa jurídica em relação aos crimes de natureza ambiental, ainda remanescia grande dissidência doutrinária a respeito da necessidade de nas lides cujo réu seja a pessoa jurídica, ter a necessidade de figurar como litisconsorte passivo necessário as pessoas naturais responsáveis pela gestão empresarial (teoria da dupla imputação).

A Teoria da Dupla Imputação é aquela segundo a qual a responsabilização penal da pessoa jurídica apenas seria possível caso houvesse concomitantemente a responsabilização de uma pessoa física, por acreditar ser necessário atrelar a culpabilidade da pessoa física com a responsabilização da pessoa jurídica. Ela decorre da interpretação da parte final do mencionado art. $3^{\circ}$ da Lei $n^{\circ} .9 .605 / 98$ (BRASIL, 1998). Haveria uma correlação entre a responsabilidade penal da pessoa jurídica e a responsabilidade penal das pessoas naturais ocupantes de cargos de gestão, 
pelo que deveria haver a formação de um litisconsórcio passivo necessário entre elas em toda denúncia penal promovida em face da pessoa jurídica.

Dito isso, chega-se ao segundo momento de análise desse projeto, uma vez que mesmo depois de ultrapassada a discussão acerca da, já abordada, possibilidade de responsabilização penal da pessoa jurídica causadora de dano ambiental, subsistia dissenso acerca da necessidade de imputação da teoria da dupla imputação para que ocorresse essa responsabilização penal da pessoa jurídica. De modo que, a respeito desse segundo momento, os tribunais e a doutrina, inicialmente, afirmavam que somente seria possível a responsabilização penal da pessoa jurídica se houvesse concomitantemente a responsabilização da pessoa física a ela vinculada.

Até o ano de 2013, o entendimento do Superior Tribunal de Justiça, expresso no Recurso Especial no 564.960 - SC, (Superior Tribunal de Justiça, 2005) era de que para que houvesse a imputação da responsabilidade penal às pessoas jurídicas, era necessário que também se operasse a das pessoas físicas que supostamente estariam ligadas ao ilícito penal, de modo que, para ser possível a propositura de ação penal em face do ente coletivo era necessária a imputação dos dirigentes concomitantemente. Além disso, a pessoa física e pessoa jurídica deveriam constar conjuntamente e obrigatoriamente na denúncia promovida pelo Ministério Público, sob pena de a exordial sequer ser recebida. In verbis:

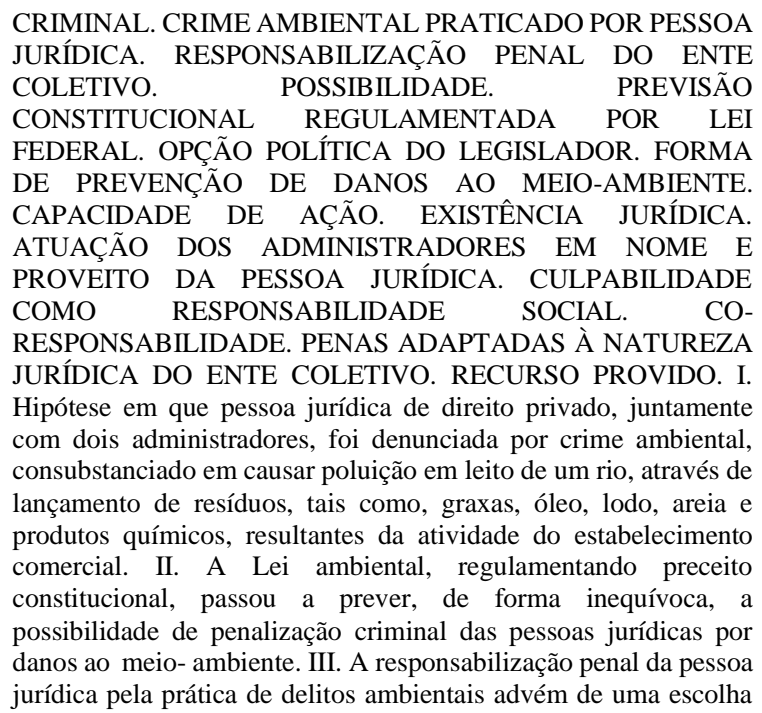


política, como forma não apenas de punição das condutas lesivas ao meio-ambiente, mas como forma mesmo de prevenção geral e especial. IV. A imputação penal às pessoas jurídicas encontra barreiras na suposta incapacidade de praticarem uma ação de relevância penal, de serem culpáveis e de sofrerem penalidades. V. Se a pessoa jurídica tem existência própria no ordenamento jurídico e pratica atos no meio social através da atuação de seus administradores, poderá vir a praticar condutas típicas e, portanto, ser passível de responsabilização penal. VI. A culpabilidade, no conceito moderno, é a responsabilidade social, e a culpabilidade da pessoa jurídica, neste contexto, limita-se à vontade do seu administrador ao agir em seu nome e proveito. VII. A pessoa jurídica só pode ser responsabilizada quando houver intervenção de uma pessoa física, que atua $\mathrm{em}$ nome e em benefício do ente moral. VIII. "De qualquer modo, a pessoa jurídica deve ser beneficiária direta ou indiretamente pela conduta praticada por decisão do seu representante legal ou contratual ou de seu órgão colegiado.”. IX. A atuação do colegiado em nome e proveito da pessoa jurídica é a própria vontade da empresa. A coparticipação prevê que todos os envolvidos no evento delituoso serão responsabilizados na medida se sua culpabilidade. X. A Lei Ambiental previu para as pessoas jurídicas penas autônomas de multas, de prestação de serviços à comunidade, restritivas de direitos, liquidação forçada e desconsideração da pessoa jurídica, todas adaptadas à sua natureza jurídica. XI. Não há ofensa ao princípio constitucional de que "nenhuma pena passará da pessoa do condenado...", pois é incontroversa a existência de duas pessoas distintas: uma física - que de qualquer forma contribui para a prática do delito - e uma jurídica, cada qual recebendo a punição de forma individualizada, decorrente de sua atividade lesiva. XII. A denúncia oferecida contra a pessoa jurídica de direito privado deve ser acolhida, diante de sua legitimidade para figurar no pólo passivo da relação processual-penal. XIII. Recurso provido, nos termos do voto do Relator. (STJ - REsp: 564960 SC 2003/0107368-4, Relator: Ministro GILSON DIPP, Data de Julgamento: 02/06/2005, T5 - QUINTA TURMA, Data de Publicação: DJ 13.06.2005 p. 331RDR vol. 34 p. 419, grifos nossos.)

Contudo, verificou-se que a adoção da teoria da dupla imputação, esvaziaria o instrumento trazido pela Constituição Federal (art. 225, §3º (BRASIL, 1988), que se destina a proteger os bens jurídicos ambientais que merecem uma repressão específica, deixando-os sem o devido respaldo legal por tornar a lei meramente simbólica.

Assim, em agosto de 2013, a $1^{\circ}$ Turma do Supremo Tribunal Federal no julgamento do Recurso Extraordinário no 548.181/PN (Supremo Tribunal Federal, 2013) por 3 votos a 2, alterou o posicionamento, para reconhecer a desnecessidade da dupla imputação para a responsabilização criminal da pessoa jurídica, sob o fundamento de que o art. $225, \S 3^{\circ}$, da 
Constituição Federal (BRASIL, 1988) "não teria condicionado a responsabilização penal da pessoa jurídica por crimes ambientais à simultânea persecução penal da pessoa física em tese responsável no âmbito da empresa.", possibilitando, assim, que as ações fossem propostas somente em face da pessoa jurídica causadora do ilícito.

O referido julgado estabeleceu a desnecessidade da dupla imputação pelo seguinte:

(...). O art. $225, \S 3^{\circ}$, da Constituição Federal não condiciona a responsabilização penal da pessoa jurídica por crimes ambientais à simultânea persecução penal da pessoa física em tese responsável no âmbito da empresa. A norma constitucional não impõe a necessária dupla imputação. 2. As organizações corporativas complexas da atualidade se caracterizam pela descentralização e distribuição de atribuições e responsabilidades, sendo inerentes, a esta realidade, as dificuldades para imputar o fato ilícito a uma pessoa concreta. 3. Condicionar a aplicação do art. $225, \$ 3^{\circ}$, da Carta Política a uma concreta imputação também a pessoa física implica indevida restrição da norma constitucional, expressa a intenção do constituinte originário não apenas de ampliar o alcance das sanções penais, mas também de evitar a impunidade pelos crimes ambientais frente às imensas dificuldades de individualização dos responsáveis internamente às corporações, além de reforçar a tutela do bem jurídico ambiental. 4. A identificação dos setores e agentes internos da empresa determinantes da produção do fato ilícito tem relevância e deve ser buscada no caso concreto como forma de esclarecer se esses indivíduos ou órgãos atuaram ou deliberaram no exercício regular de suas atribuições internas à sociedade, e ainda para verificar se a atuaçãose deu no interesse ou em benefício da entidade coletiva. Tal esclarecimento, relevante para fins de imputar determinado delito à pessoa jurídica, não se confunde, todavia, com subordinar a responsabilização da pessoa jurídica à responsabilização conjunta e cumulativa das pessoas físicas envolvidas. Em não raras oportunidades, as responsabilidades internas pelo fato estarão diluídas ou parcializadas de tal modo que não permitirão a imputação de responsabilidade penal individual.

Essa mudança de entendimento significou um avanço muito interessante para a tutela do direito fundamental ao meio ambiente equilibrado, pois permitiu o reforço da tutela do bem jurídico ambiental, evitando a impunidade.

Muito embora o supracitado Recurso Extraordinário (Supremo Tribunal Federal, 2013) não possuísse caráter vinculante, o Superior Tribunal de Justiça, a partir de 2014, alterou o seu posicionamento (Superior Tribunal de Justiça, 2014) passando a reconhecer a 
desnecessidade da dupla imputação para adotar entendimento uníssono ao Supremo Tribunal Federal, in verbis:

HABEAS CORPUS SUBSTITUTIVO DE RECURSO ORDINÁRIO. NÃO- CABIMENTO. PROCESSUAL PENAL. CRIMES DOS ARTS. 54, CAPUT, E 60, AMBOS DA LEI N. ${ }^{\circ}$ 9.605/98. TRANCAMENTO DA AÇÃO PENAL. MEDIDA EXCEPCIONAL. DENÚNCIA GERAL. POSSIBILIDADE. INÉPCIA NÃO CONFIGURADA. ATIPICIDADE DA CONDUTA ENQUADRADA COMO CRIME DE POLUIÇÃO. NECESSIDADE DE DILAÇÃO PROBATÓRIA. VIA ELEITA INADEQUADA. EXCLUSÃO DA PESSOA JURÍDICA DO POLO PASSIVO DA AÇÃO PENAL. INVIABILIDADE. AUSÊNCIA DE FLAGRANTE ILEGALIDADE QUE PERMITA A CONCESSÃO DE ORDEM EX OFFICIO. ORDEM DE HABEAS CORPUS NÃO CONHECIDA. 1. A Primeira Turma do Supremo Tribunal Federal e ambas as Turmas desta Corte Superior, após evolução jurisprudencial, passaram a não mais admitir a impetração de habeas corpus em substituição ao recurso ordinário, nas hipóteses em que esse último é cabível, em razão da competência do Pretório Excelso e deste Tribunal Superior tratar-se de matéria de direito estrito, prevista taxativamente na Constituição da República. 2. Entretanto, a impetração de writ substitutivo de recurso ordinário não impede a concessão de ordem de habeas corpus de ofício, em situações de flagrante ilegalidade. 3. A teor do entendimento desta Corte, é possível o oferecimento de denúncia geral quando uma mesma conduta é imputada a todos os acusados e, apesar da aparente unidade de desígnios, não há como pormenorizar a atuação de cada um dos agentes na prática delitiva. No caso, a denúncia não é inepta, mas apenas possui caráter geral, e tampouco prescinde de um lastro mínimo probatório capaz de justificar o processo criminal. Precedentes. 4. Nos crimes de autoria coletiva, é prescindível a descrição minuciosa e individualizada da ação de cada acusado, bastando a narrativa das condutas delituosas e da suposta autoria, com elementos suficientes para garantir o direito à ampla defesa e ao contraditório, como verificado na hipótese. 5. " $[\mathrm{O}] \mathrm{s}$ denunciados causaram poluição em nível possível de resultar danos à saúde humana, bem como fizeram funcionar estabelecimento potencialmente poluidor contrariando as normas legais e regulamentares pertinentes." Tais fatos, em tese, amoldam-se aos tipos penais descritos nos arts. 54 e 60, ambos da Lei n. ${ }^{\circ}$ 9.605/98, a evidenciar que a denúncia atende o disposto no art. 41 do Código do Processo Penal, sendo inviável o prematuro encerramento da persecução penal. 6. A alegação de que o crime de poluição não se configurou, ante a falta de comprovação de perigo concreto à saúde humana, esbarra na necessidade de dilação probatória, incompatível com a via estreita do habeas corpus. 7. A pessoa jurídica também denunciada deve permanecer no polo passivo da ação penal. Alerte-se, em obiter dictum, que a Primeira Turma do Supremo Tribunal Federal reconheceu que a necessidade de dupla imputação nos crimes ambientes viola o disposto no art. 225, 3. ${ }^{\circ}$, da Constituição Federal (RE 548.818 AgR/PR, 1. ${ }^{\text {a Turma, Rel. Min. ROSA WEBER, Informativo n. }}{ }^{\circ}$ 
714/STF). 8. Ausência de patente constrangimento ilegal que, eventualmente, imponha a concessão de ordem ex officio. 9. Ordem de habeas corpus não conhecida. (HC 248.073/MT, Rel. Ministra LAURITA VAZ, QUINTA TURMA, julgado em 01/04/2014, DJe 10/04/2014, grifos nossos).

Portanto, atualmente está se caminhando no sentido de pacificação nos tribunais superiores da desnecessidade da aplicação da teoria da dupla imputação para que se possa responsabilizar penalmente a Pessoa Jurídica, em virtude, não só da dificuldade de individualização de conduta, mas também porque ao condicionar a procedibilidade da ação à imputação criminal da pessoa física conjuntamente à pessoa jurídica, estaria se condenando as denúncias ao fracasso, pois estas seriam ineptas, uma vez que a responsabilidade penal objetiva está extirpada do ordenamento jurídico pátrio.

Dito de outro modo, hoje, pode-se dizer que a jurisprudência está caminhando no sentido de reconhecimento da desnecessidade da dupla imputação, a fim de que seja assegurada maior eficácia à preservação ambiental, uma vez que a possibilidade de responsabilização autônoma da Pessoa Jurídica acaba servindo como instrumento de redução de práticas de condutas delitivas ao meio ambiente.

\section{CONSIDERAÇÕES FINAIS}

Diante de todo o exposto no curso do presente projeto, é possível concluirmos que este se baseou em duas questões essenciais à compreensão do instituto da responsabilidade penal da pessoa jurídica pela prática de crimes ambientais, fazendo uma análise da real possibilidade de aplicação desse tipo de responsabilidade às pessoas jurídicas, e uma segunda análise que se destinou a estudar a necessidade ou desnecessidade de aplicação da teoria da dupla imputação para que de fato seja possível a aplicação do referido instituto.

Em que pese ter sido um tema muito controvertido na doutrina e na jurisprudência do ordenamento jurídico pátrio, tais questões se encontram hoje caminhando no sentido de que é plenamente possível que as pessoas jurídicas sofram sanções penais e respondam penalmente pelos seus ilícitos ambientais. 
É certo que os parâmetros utilizados para a responsabilização penal das pessoas jurídicas não podem ser idênticos aos usados para a responsabilização de pessoas físicas capazes de serem individualizadas.

É necessário que a responsabilização criminal da pessoa jurídica seja analisada sob uma perspectiva diferenciada, de modo que seja compreendida sob uma concepção de âmbito social.

É mister ressaltar também que outro ponto controvertido era a necessidade ou desnecessidade de aplicação da teoria da dupla imputação, de modo que, para que houvesse a responsabilização penal das pessoas jurídicas, fosse necessária a concomitante responsabilização das pessoas físicas por elas responsáveis.

Conforme se observa nas ponderações deste presente estudo, em que pese ter sido este um ponto extremamente questionado pelos operadores do direito, atualmente, STJ e STF se posicionam no sentido de ser desnecessária a sua aplicação, sob pena de esvaziar os próprios preceitos constitucionais e infraconstitucionais oriundos do ordenamento jurídico pátrio.

Assim, conclui-se pelo necessário reconhecimento da responsabilização criminal das pessoas jurídicas causadoras de crimes ambientais, independentemente de aplicação da teoria da dupla imputação. Isto porque, este é um instrumento capaz de evitar a impunidade das grandes corporações, e também, porque o direito fundamental ao meio ambiente equilibrado deve ser resguardado e protegido de forma efetiva e preventiva pelo ordenamento brasileiro, o que se torna possível diante da responsabilização mais severa aplicada àqueles que causam o dano.

Dito isso, tem-se, portanto, que a responsabilidade penal da pessoa jurídica pela prática de crimes ambientais é pacificamente reconhecida no ordenamento jurídico brasileiro, e independe da responsabilização simultânea da pessoa física por ela responsável, dito de outra forma, desnecessária a aplicação da teoria da dupla imputação, conforme posição uníssona dos Tribunais Superiores.

\section{REFERÊNCIAS BIBLIOGRÁFICAS}

BITENCOURT, Cézar Roberto. Reflexões sobre a responsabilidade penal da pessoa jurídica. In: GOMES, Luis Flávio (coordenador). Responsabilidade Penal da Pessoa Jurídica e Medidas Provisórias e Direito Penal. São Paulo: Editora Revista dos Tribunais. 1999. 
BRASIL. Supremo Tribunal Federal. Pleno. Ação Direta de Inconstitucionalidade $\mathbf{N}^{\circ}$ 3540- 1/DF Relator Ministro Celso de Mello, julgado em 03/02/2015, publicado em DJe-025, divulgado em 05/02/2015, publicado em 06/02/2015. Disponível em: <

http://portal.stf.jus.br/processos/detalhe.asp?incidente=2311268>. Acesso em: 16 de nov. de 2019.

Supremo Tribunal Federal. Recurso Extraordinário N 548181/PR, 2013, Relatora Ministra Rosa Weber, julgado em 06/08/2013, publicado em Acórdão Eletrônico DJe-213, divulgado em 29/10/2014, publicado em 30/10/2014. Disponível em:

$<$ http://portal.stf.jus.br/processos/detalhe.asp?incidente=2518801> Acesso em: 16 de nov. de 2019.

BRASIL. Superior Tribunal de Justiça. Recurso em Habeas Corpus No 40317/SP, 2013, Relator Ministro Jorge Mussi, julgado em 22/10/2013, publicado em DJe 29/10/2013. Disponível em: 〈https://ww2.stj.jus.br/websecstj/cgi/revista/REJ.cgi/ITA?seq=1275789\&tipo=0\&nreg=201302 $713671 \&$ SeqCgrmaSessao $=\&$ CodOrgaoJgdr $=\& d t=20131029 \&$ formato $=P D F \&$ salvar $=$ false $>$. Acesso em: 16 de nov. de 2019.

Superior Tribunal de Justiça. Recurso em Habeas Corpus No 53208/SP, 2015, Relator Ministro Sebastião Reis Júnior, julgado em 21/05/2015, publicado em DJe 01/06/2015. Disponível em: <https://ww2.stj.jus.br/processo/revista/documento/mediado/?componente=ITA\&sequencial= $1410084 \&$ num_registro $=201402833830 \&$ data $=20150601 \&$ formato $=P D F>$. Acesso em: 16 de nov. de 2019.

. Superior Tribunal de Justiça. Recurso em Habeas Corpus No 248073/MT, 2014, Relatora Ministra Laurita Vaz, julgado em 01/04/2014, publicado DJe em 10/04/2014. Disponível em: <https://ww2.stj.jus.br/processo/revista/documento/mediado/?componente=ITA\&sequencial= $1310779 \&$ num_registro $=201201411879 \&$ data $=20140410 \&$ formato $=P D F>$.Acesso em: 16 de nov. de 2019.

. Superior Tribunal de Justiça. Recurso em Mandado de Segurança 39173/BA, 2015, Relator Ministro Reynaldo Soares da Fonseca, julgado em 06/08/2015, publicado em DJe 13/08/2015. Disponível em:

<https://ww2.stj.jus.br/websecstj/cgi/revista/REJ.cgi/ITA?seq=1425899\&tipo=0\&nreg=2012 $02031379 \&$ SeqCgrmaSessao $=\&$ CodOrgaoJgdr $=\& \mathrm{dt}=20150813 \&$ formato=PDF $\&$ salvar $=$ false $>$. Acesso em: 16 de nov. de 2019.

. Superior Tribunal de Justiça. Recurso em Mandado de Segurança 49721/PA, 2016, Relator Reynaldo Soares da Fonseca, julgado em 10/05/2016, publicado em DJe 27/05/2016. Disponível em: $<$ https://ww2.stj.jus.br/websecstj/cgi/revista/REJ.cgi/ITA?seq=1510630\&tipo=0\&nreg=201502 $821842 \&$ SeqCgrmaSessao $=\&$ CodOrgaoJgdr $=\& d t=20160527 \&$ formato=PDF $\&$ salvar $=$ false $>$. Acesso em: 16 de nov. de 2019.

. Superior Tribunal de Justiça. Recurso em Mandado de Segurança No 16.696/PR, 2006, Relator Hamilton Carvalhido, julgado em 11/04/2006, publicado em 05/02/2007. Disponívelem: <https://ww2.stj.jus.br/websecstj/cgi/revista/REJ.cgi/ITA?seq=605694\&tipo=0\&nreg=20030 $1136144 \&$ SeqCgrmaSessao $=\&$ CodOrgaoJgdr $=\& d t=20060313 \&$ formato $=P D F \&$ salvar $=$ false $>$. Acesso em 16 de nov. de 2019.

. Superior Tribunal de Justiça. Recurso Especial No 564960/SC, 2005, Relator Ministro Gilson Dipp, julgado em 02/06/2005, publicado em DJ 13/06/2005. Disponível em: < https://ww2.stj.jus.br/processo/revista/documento/mediado/?componente=ITA\&sequencial=5 54040\&num_registro $=200301073684 \&$ data $=20050613 \&$ formato $=P D F>$. Acesso em: 16 de nov. de 2019. 
Superior Tribunal de Justiça. Recurso Especial No 610.114/RN, 2005, Relator Ministro Gilson Dipp, julgado em 17/11/2005, publicado em DJe 19/12/2005. Disponível em: <https://ww2.stj.jus.br/processo/revista/documento/mediado/?componente=ITA\&sequencial= $594465 \&$ num_registro $=200302100870 \&$ data $=20051219 \&$ formato $=P D F>$. Acesso em: 16 de nov. de 2019.

BRASIL. Tribunal Regional Federal da $4^{\text {a }}$ Região. Mandado de Segurança $\mathbf{N}^{\mathbf{0}}$ 013843/PR 2002.04.01.013843-0, 2016, Relator Juiz Convocado Gilson Luiz Inácio, julgado em 21/06/2016, publicado em D.E. 28/06/2016. Disponível em: < https://www2.trf4.jus.br/trf4/processos/visualizar_documento_gedpro.php?local=trf4\&docum ento $=8367267 \&$ hash $=56 c c c 6 a 23 a 662 b 7827 c 4911863 a 28563>$. Acesso em 16 de nov. de 2019.

BRASIL. Constituição da República Federativa de 1998. Disponível em:

<http://www.planalto.gov.br/ccivil_03/constituicao/constituicao.htm.> Acesso em: 15 de nov. 2019.

BRASIL. Lei $\mathbf{n}^{\mathbf{0}}$ 9.605, de 12 de fevereiro de 1998. Disponível em:

<http://www.planalto.gov.br/ccivil_03/leis/19605.htm.> Acesso em 16 de nov. 2019

BRASIL. Lei $\mathbf{n}^{\mathbf{0}}$ 11.719, de 20 de junho de 2008. Disponível em <http://www.planalto.gov.br/ccivil_03/_Ato2007-2010/2008/Lei/L11719.htm>. Acesso em 16 de nov. de 2019.

COSTA, José de Faria. A responsabilidade jurídico-penal da empresa e dos seus órgãos (ou uma reflexão sobre a alteridade das pessoas coletivas, à luz do direito penal). Revista Portuguesa de Ciência Criminal, n.4, p. 537-559, out.-dez, 1992.

FREITAS, Vladimir Passos. Direito Ambiental em Evolução. 2.ed. Curitiba: Juruá, 2002. GIERKE, Otto Von. Die Genossenschftstheorie und die deutssche Recchtsprechnung, Berlim. 1887.

GOMES, Luiz Flávio; CUNHA, Rogério Sanches (Coord.). Legislação Criminal Especial. São Paulo: RT, 2009.

SIRVINSKAS, Luis Paulo. Tutela penal do meio ambiente. 3.ed. São Paulo: Saraiva, 2004. 